\title{
POLICIES TOWARDS INWARD FOREIGN INVESTMENT
}

Roland Brown, Mike Faber and Max Sisulu

\section{BACKGROUND - THE NEED FOR INCREASED INVESTMENT'}

The aims of any democratic government are best achieved in a growing economy, which in South Africa's case will be fuelled in the first instance by the removal of the costs, the distortions and the inefficiencies caused by apartheid and other discriminatory policies; by the removal of those sanctions imposed by the world against the apartheid regime which have served to prevent or limit economic growth; and by a release and fuller use of the energy and ingenuity of all South Africa's citizens.

But accelerated growth will also require an increase in investment. By far the largest part of this investment should be financed by domestic savings and domestic effort. That is both desirable and necessary. Public sector surpluses and subscriptions to government loans will be needed to finance a broadening of the state's infrastructure. Reinvestment of retained company profits, investments and loans by financial institutions, and the savings of individuals will continue to finance most private sector expansion. Given the importance that is attached to achieving a stable financial framework (e.g. the avoidance of unmanageable budget and balance of payments deficits), these objectives themselves imply recognition of the need to create a political economy in which companies and individuals have both the opportunity to save and the incentive to invest. Out of their growing proportion of national income, an increasing share of those savings and investments will be made by the majority African population.

But there will also be scope and need for some inward foreign investment. It should be the policy to encourage this so long as it occurs on terms consistent with the government's developmental goals. South Africa has abundant natural resources and human potential, but private inward investment will also be needed (a) to augment domestic savings,

${ }^{1}$ This article is based upon a study that was commissioned at the request of the African National Congress (ANC) and the Congress of South African Trade Unions provided the return on such inward investment is greater than its servicing costs; (b) to introduce state-of-the-art technology; (c) to provide appropriate management skills; and (d) to facilitate access to foreign markets. Foreign investors will be particularly encouraged to invest in activities which lead to increased employment and the development of local technological capacity.

It may also be in the interests of the country for the government to allow outward productive investment by South African companies in circumstances which will lead to the expansion of trade. The opportunities for intra-African trade are especially attractive.

\section{CHANGING ATTITUDES TOWARDS INWARD FOREIGN INVESTMENT}

Over the last decade there has been a marked change in the attitude of most developing countries to foreign direct investment and to the role of transnational corporations (TNCs) in the investment process. Until the tide began to turn in the second half of the 1970s there had been a period of confrontation in which the relations between host countries and TNCs had rapidly deteriorated. The build up to a confrontation coincided with the emergence of a number of developing countries from colonial status, and world wide there was a disposition to ask critical questions about the role of TNCs. In some countries the activities of TNCs were seen as a threat or potential threat to sovereignty and throughout the developing world there was much scepticism about the benefits of foreign direct investment. These negative perceptions were particularly evident in the context of natural resource projects. The old style concessions often granted in a colonial or neo-colonial setting, and sometimes in very dubious circumstances, seemed to many developing countries to have deprived them of a significant part of their patrimony.

(COSATU), and funded by the United Nations Centre on Transnational Corporations (UNCTC). 
The mood today is very different and changing attitudes had become very apparent long before the collapse of the command economies of Eastern Europe and the Soviet Union. In many developing countries there is still a good deal of wary scepticism about the benefits of foreign investment, but most of the tension has gone out of the relationship between host countries and TNCs. Not many developing countries would now see the activities of TNCs as a threat to their sovereignty, or to their growth potential. The influence of TNCs on international economic activity has indeed grown to be very great but it is an influence not generally exerted over or on behalf of any single national government, but rather according to its own logic. Countries with particular resource endowments in terms of labour, skills, natural resources or even location have been able to take advantage of TNC investments to increase employment, exports and government revenues, to improve living standards, and even to enhance their own national economic power. In particular TNC inward investment, correctly handled, has proven to be an effective way of enhancing domestic management capacity and technological skills. There are, of course, continuing areas of concern, in particular with regard to the labour practices of some of the 'footloose' industries and to the ability of TNCs to concentrate their profits in low-tax havens through transfer pricing and other equivalent practices. But, taking a broad perspective, by and large the worst fears that newly independent governments had concerning the threats that inward direct investment would pose to their sovereignty or their ability to implement their own preferred economic policies have proven to be ungrounded, and there is certainly now a new and more pragmatic approach.

The present climate of received economic opinion stresses the benefits of inward foreign investment and in particular of equity investment which does not create loan servicing obligations. With the globalization of production in the world economy and the integration of capital markets, the case for equity investment has indeed become stronger, providing that such investment is positive in terms of foreign exchange and is internationally competitive. These latter provisos are very important. Capitalintensive investment whose primary objective is to take advantage of high tariff protection in domestic markets may actually reduce income in the recipient country. But the better way to safeguard an economy against such negative effects is now deemed to be by implementing a sound trade policy (i.e. by maintain- ing a competitive exchange rate and avoiding excessive levels of effective protection) rather than by attempting to regulate too precisely inward flows of foreign investment.

\section{THE SPECIAL CASE OF SOUTH AFRICA}

Any government considering a regime for foreign investment and looking at the experience of other countries needs to start that process by taking a good look at itself. There are certain special features of the situation in South Africa and of the South African economy which need to be kept in mind.

1 South Africa's economy is large, complex and many sided. It covers manufacturing, the exploitation of natural resources most notably in the mining industry and the provision of a wide range of services including financial services.

2 Existing investment in South Africa includes foreign investment but is predominantly of local origin.

3 There is in South Africa a remarkable concentration of economic power in the hands of a very small number of corporate players who control diffuse but extremely powerful conglomerate groups. Because of the distortions introduced into South Africa by the apartheid system it cannot be assumed that protecting that group from competition from outside investors will confer any benefit on Black South Africans, the dispossessed of the Apartheid era.

4 Outside the mining sector relatively few South African firms are internationally competitive despite the fact that by comparison with neighbouring countries, South Africa possesses considerable technological skills.

5 South Africa has a sophisticated legal structure which has served an active and growing business sector for over a hundred years. Parts of that system may be in need of reform but the framework and building blocks are already in place on site.

6 Post apartheid South Africa will be engaged in a process of change which may aptly be described as revolutionary. The changes that have to be made in order to ensure a more just and humane society will affect every aspect of South African life, and no individual or company will be able to stand back from the process or refuse to participate. For business $\mathrm{ANC}^{\prime}$ s commitment to affirmative action will 
certainly impose a new range of obligations, and there will be new laws dealing with employment practices, with housing, with training, with trade union rights, with the rights of women, with access to land and with the impact on the environment of manufacturing and mining operations. Foreign investors will be subject like everyone else to this new dispensation, and will not expect to have exemptions, or be permitted to assume a posture of detached indifference. However, it would not be realistic to envisage that a Foreign Investment Code will be at the leading edge of structural change in South African society.

\section{THE GENERAL CASE FOR AN OPEN POLICY WITH SAFEGUARDS}

One starting point is to say that, subject to a few special exceptions, all foreign investment is welcome without a process of prior approval. Foreign investors will get national treatment. They will enjoy the same rights and be subject to the same obligations as a national engaged in similar activity. With regard to foreign exchange remittances the foreign investor in this category will, for better or worse, have to live with the regime which the Central Bank may ordain from time to time.

Most countries which adopt an open policy give themselves scope for some reservations. Although the cornerstone of the policy may be an open house it is usual to find that there are some exceptions and the code will give the Minister power to exclude foreign investors from participating in certain activities. In Namibia, which enacted a new investment code in December 1990, there was concern that some very small investments might be made by foreigners in businesses which could perfectly well be carried on by Namibians who might not have many other opportunities. (Hairdressing and retail trading were mentioned in the policy statement.) In other countries a ring has been drawn around financial institutions and in others, around participation in defence industries or in the media.

In almost all countries there are special scrutiny and approval procedures which apply to investments in certain sectors whether they are made by locals or by foreigners. Most important in that respect, particularly for South Africa, is the natural resources sector - mining, petroleum, forestry and fishing. With mining, for example, one finds that outside the United States of America minerals in the ground are nor- mally the property of the State and no one can prospect for minerals or mine without the grant of a licence. In contemporary practice a prospecting licence will not be granted except in return for a substantial commitment to an exploration work programme and minimum expenditures. These matters are therefore normally for negotiation between the government and the mining companies, and mining laws have their own built-in approval procedures. The grant of fishing or of felling licenses will be subject to similar regulation and procedures.

Most governments recognize however that national treatment may not always be sufficient to attract foreign investors interested in major projects, and in the type of regime we are now looking at a special status may be offered to investments which have been submitted for scrutiny and approval. An investment which is approved will then be entitled to the benefit of certain guarantees and may also be entitled to a range of fiscal incentives - tax holidays, accelerated depreciation, unlimited loss carry forward and so on.

National treatment offered to foreign investors implies that the foreign investor will in all respects abide by the local law. In an emergent South Africa that will be especially important where new laws and regulations will be a key element in the dynamics of post apartheid change.

\section{THE BASICS OF A POLICY TOWARDS INWARD INVESTMENT}

Inward private investment is seen as playing an important role in diffusing the present concentration of ownership in South African industry, in modernizing production methods, in improving competitiveness and in providing opportunities for emerging African businesses and managers. Obligations should apply in respect of training, trade union recognition, fair working practices, the need for affirmative action, attention to environmental protection and other matters, but these will be no different from those applying to domestic businesses. The experience of South East Asia has been that the more foreign capital and the more foreign managers and experts come in, and the more they interact with nationals of the recipient country, the quicker these nationals have learnt. Within a generation they become able not only to work alongside the foreign experts but to export their own management and technical skills. 
Inward investors wishing to bring capital into South Africa for either direct or portfolio investment should not normally be subject to any restrictions or be entitled to any privileges other than those applying to domestic private investors. The intention should be to encourage and welcome such foreign investment on the same terms and conditions as will be available to domestic investors. The scope for such foreign investment should be limited only in respect of certain specified sectors, which will be publicized in advance and which may be expected to include activities which impinge upon public security, mass communications, and access to certain types of classified land.

There should also be an opportunity for foreign investors contemplating bringing in more than the equivalent of $\$ 1$ million towards directly productive forms of investment to apply to have such investment registered as 'Special Status Investments'. Such 'Special Status Investments' will enjoy certain exceptional guarantees mainly in regard to the expatriation of foreign exchange but may also be made subject to a commitment to special obligations on the part of the investor. (The Appendix provides a summary of the key elements relating to Special Status Investments.)

Inward portfolio investment should also be welcomed since this will tend to increase the resources available to finance industrial expansion and may also lead to a diversification in the concentration of ownership. In general, however, foreign shareholders making portfolio investments should not be treated any more favourably, or any less favourably, than domestic shareholders.

\section{MEASURES TO PROMOTE AND PROTECT NEW LOCAL BUSINESSES}

To be appropriate for a democratic South Africa with a thriving 'mixed economy' any investment policy will have to take cognizance of the special position of members of previously disadvantaged groups who will be wanting to start their own businesses. Such persons will require special assistance in terms of training, commercial support, access to capital and in other ways, and may also require a measure of protection against early competition.

For many aspiring Black businessmen and businesswomen, the problem will be how to get started - how to find a place and to break into the established order of production and trade. The changing pattern of demand that will follow a changing distribution of disposable income is one factor that should make the process easier. Special facilities for the encouragement and support of small businesses (such as extension services and venture capital facilities) will be another. A limited influx of outside entrepreneurs bringing in capital and a culture that is different from that which has hitherto prevailed in white South African business circles should also help both by providing opportunities for black businesses to form joint ventures with such newcomers and by expanding the demand for such goods and services, as a small business will often be in the best position to supply. The influx of such smaller entrepreneurs not being offered special privileges does need to be limited and controlled, however, because certain categories of such people may be professional practitioners, technicians or tradesmen specializing in precisely those areas of work which hitherto underprivileged South Africans will themselves be aspiring to move into. The most appropriate way to deal with this problem will not in general be by legislating against or restricting the influx of foreign capital as such, but through carefully drawn and administered immigration controls. The existence of the problem does however suggest that there will need to be a certain minimum sum derived from their own resources that all immigrants intending to start a business will be required to show that they will be bringing into the country before being granted the required work permit or immigrant's visa.

There is one important financial restriction which would not apply to domestic investors but which should remain in force for foreign investors. It is common for governments to place restrictions on the local borrowings of companies that are owned or controlled by non-residents, or in which non-residents own a significant shareholding. The purpose of such a restriction is to ensure proper capitalization of foreign investments. Where local borrowing facilities are available to such companies, approval may also be required before profits and dividends are remitted abroad. The promulgation of such regulations are normally the responsibility of the Central Bank, as are the issues of any necessary approvals or authorizations, but it is normal for a Foreign Investment Code to refer to the existence of such restrictions, and we would expect this to be the case in respect of any future South African investment code. 


\section{SPECIAL REQUIREMENTS OF FOREIGN INVESTORS}

Much the most important requirements in practice for most foreign investors are guarantees relating to foreign exchange. The foreign investor needs to feel confident that foreign exchange will be available:

1 to pay for the imports necessary to keep the business going and, when necessary, for professional advice and technical assistance;

2 in the case of loans in foreign exchange approved by the Central Bank to repay the principal sum due and to pay interest and service charges as they fall due;

3 to pay licence fees and royalties due to persons resident outside the host country, subject to such constraints as may be imposed under legislation dealing with the transfer of technology;

4 to transfer after tax profits to shareholders in the form of dividends, or, in the case of companies incorporated abroad and carrying on branch operations, to make remittances to head office out of funds representing after tax profits;

5 where there has been a sale of the investment to a resident of the host country or a reduction of the share capital, to repatriate the proceeds.

A second important matter upon which a foreign investor may require assurance concerns security of title. A post-apartheid government in South Africa will certainly want to reserve to itself the right to take existing investments into public ownership. No doubt the constitution will provide for the payment of compensation for expropriated assets. However against a background of far reaching structural change it must be anticipated that foreign investors will be sensitive to the political risk factor and concerned in particular with the possibility of expropriation.

From the standpoint of a foreign investor the optimum solution in the context of an approved investment would be for the Certificate of Approval to incorporate a guarantee that the investment will not be expropriated. If that is not possible most investors would attach considerable importance to a guarantee that in the event of expropriation the amount of compensation and the manner of payment could be referred for final determination to international arbitration.
With respect to general fiscal incentives, a number of developing countries have sought to attract foreign investment by offering to approved investments a range of fiscal concessions - tax holiday, accelerated depreciation, unlimited loss carry forward, uplift on capital allowances etc. In some instances governments may see concessions as necessary in order to offset the negative effect of unusually high rates of tax which could make a particular fiscal regime uncompetitive by international standards. Other governments offering guarantees to approved investors have rejected the idea of fiscal incentives set out in a Code. Where the generally applicable rate of tax is reasonable, across-the-board incentives are seen as wasteful and unnecessary.

There are a number of reasons for rejecting the inclusion of across-the-board incentives.

1 In order to create stable conditions for economic growth, a government needs a broad revenue base which is not continuously eroded by piecemeal concessions;

2 Tax concessions may be wasteful since in many cases, if other conditions are satisfactory, such concessions will not be needed in order to attract foreign investment;

3 Double Taxation Treaties, and the unilateral double taxation relief offered by many capital exporting countries, mean that the practical effect of tax holidays is often uncertain;

4 Where in a particular sector, or in a particular region, or in connection with some particular activity, it is adjudged that a fiscal concession is required in order to attract investment, appropriate provision can be made by amendment to the existing law, which may then apply alike to both foreign and domestic investors.

In South Africa this last point is particularly important. Particular industries (such as 'high tech' industries), particular sectors or particular regions may require special treatment in order to attract investment. Likewise it may be considered desirable to encourage particular exports or specific forms of efficient import substitution. Provision for that can be made as an act of deliberate policy or in consequence of a particular negotiation either in the tax laws or through other financing 
arrangements without conferring benefits or foregoing revenue when it is not necessary to do so.

\section{THE ROLE OF A FOREIGN INVESTMENT CODE}

The role of a foreign investment code is twofold. First, it should be a vehicle for indicating and publicizing which particular categories of investment are to be favoured with special concessions and which are prohibited for foreign investors. Second, it should serve to counteract certain of the particular disadvantages that the foreign investor may labour under by comparison with the domestic investor.

\section{These particular disadvantages are normally:-}

1 the potential foreign investor may be less fully informed than the domestic investor;

2 the potential foreign investor may find it more difficult to apply for and receive the necessary consents and licenses needed before he or she can start business - although it is not anticipated that these will normally be any different than they will be for a domestic investor;

3 while the domestic investor will normally be content to receive profits, dividends, interest payments etc. in domestic currency, the foreign investor will be concerned at his or her ability to convert at least a proportion of them into foreign exchange and to repatriate capital also in the event that he or she wishes to wind up or dispose of the business;

4 in the event of nationalization, or of certain other types of dispute arising, the foreign investor may feel that as a foreigner he or she may be discriminated against by the host government or be at a disadvantage in the local courts.

Although a foreign investment code can be useful in stimulating and guiding inward foreign investment, its potential influence is limited and its effect will always be subsidiary to that of other factors. Amongst such other factors the most important are:-

1 the opportunity which the investor sees for making a profit and for enjoying the fruits of that profit;

2 the track record of the government in question in dealing with earlier foreign investment;

3 how the government of the day treats the firms and individuals in the country's own private sector.

Experience strongly suggests that if these factors are perceived to be favourable, foreign investors will seek to come whether or not there is a foreign investment code. If they are absent, investors will shy away however invitingly generous the provisions of a code may appear to be. This being so, tax holidays and exceptional capital write-offs (i.e. provisions more generous than those allowed to domestic investors) are as often as not simply a means of diminishing government revenues from an investment that would have been made anyway, or of favouring foreign investors over domestic investors, or of influencing an investment in favour of capitalintensive rather than labour-intensive techniques. If rapid capital write-downs are desirable to encourage certain types of major investments - as indeed they may be - such accelerated write-downs should be made equally available to domestic investors who can then decide for themselves whether, and in what form, to bring in foreign capital.

In short, a future South African government should generally be neutral in any measures intended to induce investment, foreign or domestic. Where tax legislation (or specific government expenditures) do favour one category of investor over another, that preference should be deliberately exercised either in favour of particular types of investment that are considered specially desirable, or in favour of particular under-developed regions, or in favour of those South African citizens who have hitherto been disadvantaged and who will need special measures to assist them to become owners, either directly or indirectly, of a significantly larger proportion of the country's productive assets. 


\section{APPENDIX}

\section{SUMMAPY OF KEY ELEMENTS RELATING TO SPECIAL STATUS INVESTMENTS}

1 A foreign investor whose investment was eligible for special status could apply to the Minister for a Certificate of Approval. In considering whether a Certificate should be issued the Minister would have regard to the extent to which the enterprise would -

a increase employment opportunities;

b provide training for South Africans and promote the spread of high level technical skills;

c earn or save foreign exchange;

d generate development in the less developed areas;

e contribute to the transfer of technology;

f contribute to the advancement of persons within South Africa who have been socially, economically or educationally disadvantaged by past discriminatory laws and practices;

make provision for equal opportunities for women;

h perform activities that would be likely to have an impact on the environment and, where necessary, take appropriate measures to deal with any adverse environmental consequences.

2 Special Status for a foreign investment would not be available:-

a for investments where capital expenditure fell below a minimum figure, or

b for portfolio investments.

3 The issue of a Certificate of Approval for a Special Status Investment will be within the discretion of the Minister, and when issued the Certificate will specify the conditions on which approval has been given.

4 The holder of a Certificate of Approval for a Special Status Investment will enjoy certain guarantees:-

\section{A GUARANTEES IN RESPECT OF FOREIGN EXCHANGE}

The holder of a Certificate will be given an undertaking that foreign exchange will be available:-

a to enable the investor in the case of loans in foreign exchange approved by the Reserve Bank to repay the principal, interest and service charges as they fall due;

b to transfer dividends to shareholders resident outside South Africa, or where the business is carried on as a branch operation of a foreign company to make remittances to head office; 
c to pay licence fees and royalties due to persons resident outside South Africa, where such payments are made under approved rules;

d in the event of the sale of a Special Status Investment or part of it, or in the event of a reduction of capital, to repatriate the proceeds; the Reserve Bank would however retain the right to require that where amounts are large transfers should be scheduled over a period of time;

In the case of a business producing for export, where the Certificate so provided, the holder could be allowed to retain off-shore the proceeds of sale after remitting sums required to meet taxes and other local obligations.

\section{B GUARANTEE RELATING TO NATIONALIZATION}

A new constitution will provide in some acceptable form for the payment of compensation for assets taken into public ownership. In the event of a dispute between Government and the holder of a Certificate of Approval concerning the amount of compensation due, or about the marner of payment, the Code would provide that the dispute could at the instance of the investor be referred to international arbitration.

5 The Certificate of Approval would remain in force only so long as the investor complies with certain reciprocal obligations. There would be two basic requirements:-

a Every investor seeking a Certificate of Approval would be required to make specific proposals for training which, once agreed, would be incorporated in the Certificate as a condition of approval. Failure to comply with the condition could lead to cancellation of the Certificate;

b Proposals of the investor relating to the investment itself would be incorporated in the Certificate and would constitute binding commitments. Failure to honour those commitments could jeopardise the continued validity of the Certificate.

6 In the event of a dispute between the Government and the holder of a Certificate of Approval about the continued validity of the Certificate, if the dispute could not be settled by agreement, it could at the instance of the investor be referred to international arbitration. 